Corrigendum

\title{
Corrigendum to "Dehydration of jambolan [Syzygium cumini (L.)] juice during foam mat drying: Quantitative and qualitative changes of the phenolic compounds" [Food Research International 102 (2017) 32-42]
}

Iasnaia Maria de Carvalho Tavares ${ }^{\mathrm{a}}$, Tuany Yuri Kuboyama Nogueira ${ }^{\mathrm{a}}$, Maria Aparecida Mauro ${ }^{\mathrm{a}}$, Sergio Gómez-Alonso ${ }^{\mathrm{b}}$, Eleni Gomes ${ }^{\mathrm{a}}$, Roberto Da-Silva ${ }^{\mathrm{a}}$, Isidro Hermosín-Gutiérrez ${ }^{\mathrm{b}, *}$, Ellen Silva Lago-Vanzela ${ }^{a}$

a São Paulo State University (Unesp), Institute of Biosciences, Humanities and Exact Sciences (Ibilce), Cristovão Colombo, 2265, Jardim Nazareth, 15054-000, Campus São José do Rio Preto, São Paulo, Brazil

${ }^{\mathrm{b}}$ Universidad de Castilla-La Mancha, Instituto Regional de Investigación Científica Aplicada, Avda. Camilo José Cela S/N, 13071 Ciudad Real, Spain

The authors regret "that the name of the first author was wrong and we did not detect at time this error during the processing of the article. The correct name for the first author is Iasnaia María de Carvalho
Tavares (I.M.C. Tavares).”

The authors would like to apologise for any inconvenience caused.

\footnotetext{
DOI of original article: http://dx.doi.org/10.1016/j.foodres.2017.09.068

* Corresponding author.

E-mail address: isidro.hermosin@uclm.es (I. Hermosín-Gutiérrez).
} 